\title{
EFFECT OF MOTIVATION ON THE INTENTION TO PARTICIPATE IN THE SCIENTIFIC PUBLICATIONS AMONG MEDICAL RECORD STAFF
}

\author{
Isnaini Qoriatul Fadhilah'), Izatul Milla'), Robiatud Daniyah's), \\ Namira Fitri Rahandiani1), Kurnia Eka Putri1)
}

\author{
1)Department of Medical Record, Health Polytechnics, Ministry of Health Semarang \\ 2)Universitas Negeri Jember, East Java, Indonesia \\ 3)Department of Medical Record, STIA Malang, East Java, Indonesia
}

\begin{abstract}
Background: A medical records personnel is in charge of managing patient health files in a facility. They provide efficient health records service to patients, medical and nursing staff. They organise, update and store records in either paper-based documents or electronic records. However, it is indicated that many medical recorders in Indonesia have not been able to fulfill one of the activities required by professional organizations, namely writing and publishing scientific papers. This study aimed to examine the effect of motivation on the intention to participate in the scientific publications among medical record staff.

Subjects and Method: A cross sectional study. A number of 100 medical record staffs who work at health facilities was selected for this study. The dependent variable was intention to participate in the scientific publication. The independent variable was motivation. The data were collected by electronic questionnaire and analyzed by Chi square. Results: Strong motivation was positively associated with intention to participate in the scientific publications among medical record staff $(\mathrm{OR}=10.60 ; 95 \% \mathrm{CI}=2.36$ to 4.48 ; $\mathrm{p}=0.029)$.

Conclusion: Strong motivation is positively associated with intention to participate in the scientific publications among medical record staff.

Keywords: motivation, intention, medical record staff

\section{Correspondence:}

Isnaini Qoriatul Fadhilah. Department of Medical Record, Health Polytechnics, Ministry of Health Semarang. Jl. Tirto Agung, Banyumanik, Kota Semarang. Email: isnainiqoriatul@gmail.com. Mobile: 089681918022.
\end{abstract}

